\title{
Common Pool Regimes: A Critique
}

\author{
Jan-Erik Lane \\ University of Freiburg, Germany \\ E-mail: janeklane@googlemail.com
}

Received: April 4, 2012

doi:10.5430/rwe.v3n2p75
Accepted: July 12, $2012 \quad$ Online Published: September 12, 2012

URL: http://dx.doi.org/10.5430/rwe.v3n2p75

\begin{abstract}
As environmental degradation increases around the globe, especially in relation to open access resources, new policies to augment sustainability have to be invented. The purpose of this paper is to provide a most concrete example of some of the difficulties involved, by means of examining recent data about the so-called Helcom regime for the Baltic Sea. The findings include that the heralded theory of common pools governance presents a too optimistic picture. Despite massive financing, the deterioration of the predicament of the important Baltic Sea has not been reversed.
\end{abstract}

Keywords: Sustainability, Common pools, CPR governance regime, PD game, Voluntary coordination, Helcom regime, Baltic Sea, Tragedy of the commons, Pollution sources, Environmental pressure

\section{Introduction}

If one wants to show that the so-called tragedy of the commons, i.e. the depletion of common pool resources modelled as an N-person PD game, can be stopped through voluntary coordination or benevolent cooperation, then where to search and find empirical examples? It may appear obvious that domestic cases like village irrigation schemes or self-policed fishing quotas as well as reciprocal schemes among peasants for pastures or grazing offer examples of such voluntary regimes. However, such domestic examples may involve indirect employment of state enforcement or threat thereof. Domestic examples could also be based upon custom that could be employed in legal repraisals against reneging. As an alternative, an enquiry into international regimes for managing the common pool may be advisable, since there exists no third party enforcer.

The theory of common pool governance entails that collective action problems involved in managing common pool resources (CPR) can be successfully handled by means of voluntary agreements (Ostrom 1990; Keohane and Ostrom 1994, Adhikari, 2001; Agrawal, 2002, 2003). One should examine this optimistic thesis both in relation to domestic collective goods and international ones. Below we will examine this argument in relation to governments as the players, engaged in the governance of the Baltic Sea as a concrete example of a large common pool. The governance theory of common pool resources claims that the players involved can overcome the so-called tragedy of the commons by creating and implementing a regime, or institutional mechanism, among the players involved, preventing rational over-exploitation, thus securing sustainability for pool resources (Young 1982, 1989, 2005, 2008). The Helcom is the regime governing the protection of the Baltic Sea as a collaboration mechanism among the sovereign states concerned.

This sustainability theory about states and the management of international common pool resources entails that the voluntary introduction and enforcement of institutions in the form of a regime could resolve the problem of dissipation of rents. We will argue to the contrary that it is not likely that governments can overcome the failure of collective action in designing a regime that counteracts the free rider problem in relation to the management of common-pool resources. The tragedy of the commons is modelled on the basis of the Prisoners' Dilemma game, expressing the logic of over-utilization of common pool resources (Hardin 1968,; Hardin. 1982; Baden and Noonan, 1998).

Below the optimistic model of common-pool management will be examined in the form of an enquiry into an empirical case of the governance of common pool resources, where information is abundant. First, the ecological predicament of the Baltic Sea shortly after the fall of the Iron Curtain will be examined. Second, the evidence today for some of the main forms of ongoing pollution and exploitation - eutrophication, heavy metals poisoning, overfishing and hypoxia will be examined. Finally, the common pool management model for overcoming the tragedy of the commons will be discussed on the basis of this empirical evaluation. 


\section{Evaluation}

The Communist state displayed negligence towards ecological matters that is on such as scale that it is difficult to understand. The term "ecocide" has been coined in order to conceptualize the state's impact upon the environmental predicament in Eastern Europe (Sandberg, 2007). As a collectivist movement, it is strange that Communism should pay such little respect to ecological or common interests. In any case, the Communist state was poor, meaning that its set of feasible activities in terms of ecology policies was small. But its set of desirable policies was perhaps even smaller (Clark and Wildavsky, 1991).

\subsection{The Common Pool of the Baltic Sea around 1990}

The Baltic Sea, a semi-closed area of about $415,000 \mathrm{~km}^{2}$, is the largest body of brackish (low salinity) water in the world and is distinguished by its division into a series of basins of varying depths. Traditionally, there has been much fishing in various parts of the sea. Its ecologic importance is without doubt immense for the nine countries that share its coastline, harbouring some 100 million people. In addition, the catchment area of the Baltic Sea is much larger, as some of the major rivers of Belorussia, the Ukraine and the Czech and Slovak Republics end in the Baltic Sea. Seven large rivers deliver about half of all the fresh water that runs into the Baltic Sea. In addition, there are some 37 other rivers that flow into the Baltic Sea. These rivers flow through a land area four times the size of the Baltic Sea itself (Helsinki Commission 1992, 5/3).

The main threats to the Baltic Sea have been the high concentrations of nutrients (phosphorus and nitrogen), the decline of oxygen, bad inflow of fresh salinity water from the North Sea and the emission of harmful or toxic substances to the sea as well as overfishing. The main negative changes in the marine environment have resulted from trends toward increasing nutrient concentrations leading to a higher biological productivity. The organic materials produced in this process consume oxygen during its microbial destruction, thus contributing to the more frequent oxygen depletion and occurrence and spread of hydrogen sulphide.

Table 1 and Table 2 show the situation around 1990, i.e. at the time of the fall of Communism, in terms of nutrient loads.

$<$ Insert Table 1 Here $>$

In the 1980s, it seems that the concentration of nutrients was stabilized at a high level (Table 2).

$<$ Insert Table 2 Here $>$

Untreated waste waters from industry, both municipal and agricultural, have been responsible for the high concentrations of nutrients in the Baltic Sea. The problems with untreated waste water were severe in the eastern Baltic area, where very often there was no treatment equipment whatsoever. Yet, in addition to direct outflow of nutrients into the Baltic, airborne pollution was responsible for 50 percent of the nitrogen load in the Baltic Sea.

The depletion of oxygen, as an effect of the nutrient concentrations, has seriously affected all living resources in the sea. The decreasing level of oxygen is significant in the deep waters, the reason being mainly the lack of inflow of fresh water from the North Sea and the Skagerrak.

Table 3 contains information about the total load of organic materials into the Baltic Sea around 1990. The figures were high enough to warrant the question about the sustainability of the ecological system of the Baltic Sea as well as the search for a coordinated policy response among the players concerned.

$<$ Insert Table 3 Here $>$

The Baltic Sea has been exposed to an extensive use of chemicals from the very beginning of the industrialization of the region in the late 19th century and its marine environment has one of the longest histories of contamination in the world. Consequently, the Baltic has often been referred to as the most polluted sea in the world.

The bad condition of the Baltic Sea used to be to a large extent the result of the pollution coming from the former Communist states (Table 4).

$<$ Insert Table 4 Here $>$

In general, Communist governments in Eastern Europe displayed low valuations of the environment in addition to harbouring exaggerated hopes about minimising ecological risks (Sandberg, 2007). Yet, also the other countries around the Baltic Sea have engaged in the exploitation of its bio-capacity. 


\subsection{The Common Pool Regime}

The first steps towards creating some kind of international regime for the handling of the environmental protection of the Baltic Sea were taken in the early 1970s. Finland initiated the negotiations between the so-called coastal states of the Baltic Sea in 1972 that were held after the United Nation's environmental conference in Stockholm the same year. The goal was to arrive at a coordinated effort to counteract the rising pollution and depletion of the Baltic Sea. In 1974 all the Baltic states signed the so-called Helsinki Convention on the Protection of the Marine Environment of the Baltic Sea Area, where Article 3 states that all states will "prevent and reduce the release of polluting materials and protect and improve the marine environment of the Baltic Sea Area" (Fitzmaurice 1992, 233). This regime went into operation in 1980, and a coordinating body was created, HELCOM (The Baltic Marine Environment Protection Commission), in order to collect information about the environmental predicament of the Baltic Sea and function as an administrative body coordinating the environmental collaboration between these states.

Concrete steps were recommended in two declarations from 1988 and 1990 at the ministerial level. In 1992 the 1974 international regime was replaced by a new one, also signed by such states in the periphery of the Baltic Sea as Norway, the Ukraine, Czechoslovakia and the EC Commission. In "The Baltic Sea Environment Declaration" the multi-lateral financing of programmes to reduce the amount of pollution entering the Baltic Sea was outlined as a method to improve the environmental condition of the Sea. In addition to the coastal states in the Baltic Area, Norway, the Czech and Slovak Federal Republics, the Ukraine and the European Economic Community signed "The Baltic Sea Joint Comprehensive Environmental Action Programme". The Action Programme targeted inter alia 132 "hot spots", which were seen as the most critical sources of pollution to the Baltic Sea. Until 2005, the International Baltic Sea Fishery Commission (IBSFC) attempted to regulate offshore fishing in the Baltic Sea region, but as all Baltic coastal states except Russia are members of the European Union since 2005, with their fisheries activities being regulated under the EU Common Fisheries Policy (EU CFP), the decision was made to close down the IBSFC. Baltic Sea fisheries are therefore being managed at the European level together with the help of an EU-Russia bilateral agreement.

The marine environment of the Baltic Sea has thus been monitored by the Helsinki Commission (HELCOM). Since 1979 the Commission has been collecting data within the frame of the Baltic Monitoring Programme (BMP). The monitoring data provided by all Baltic Sea states are stored and processed in the HELCOM Database, established by the Commission on a consultant basis. Parts of the programs of the Baltic Sea regime have been integrated into EU policy-making, involving most substantial money support besides the setting of targets.

\subsection{The Present Predicament}

Various forms of human activity have impacts on biodiversity, and the biodiversity segment of the HELCOM Baltic Sea Action Plan aims to serve as an all encompassing element reflecting the performance of the whole plan. The goal of achieving a favourable conservation status for the biodiversity of the Baltic Sea cannot be reached without comprehensively considering human activities and carrying out decisive action in other segments of the plan.

Eutrophication and hazardous substances have strong impacts on biodiversity. Some species are directly threatened by overfishing or the destruction of their habitats by human activities such as dredging and construction along shores. Intensified shipping adds to existing environmental stress by potentially introducing invasive non-native species, minor oil spills, and the increasing probability of major oil spills that could be highly destructive for many species and habitats. Together with the predicted impacts of global warming, all of these pressures increasingly threaten the biodiversity of the Baltic Sea.

Helcom now argues that progress has been significant on the path to a healthier Baltic Sea. This would mainly be due to improved waste water treatment in the Baltic, caused by the joint efforts of HELCOM member states, i.e. all the nine countries around the Baltic Sea. However, the evidence is more mixed in the most recent reports.

\subsubsection{Eutropification}

The effects of nutrient enrichment, also known as eutrophication, are perhaps the single greatest threat to the Baltic Sea environment. The main sources of excessive amounts of nitrogen and phosphorus are inadequately treated waste waters, agriculture, and airborne emissions, including the shipping sector.

From 1970 up to 2008 the overall phosphorus loads into the Baltic Sea have been cut by about a half, which can be considered a great achievement. Since 1994 the HELCOM member states have annually reported their loads to the Baltic Sea and in between 1994 and 2008 only, the overall reduction was almost 20 percent. For nitrogen the overall input has decreased as well albeit less significantly. The main reason behind this good progress is improved municipal and industrial waste water treatment in HELCOM countries. Deposition of nitrogen to the Baltic Sea has declined by one third since 1980 as a result of decreased nitrogen emissions. 
Thus, the phosphorus load from the St. Petersburg area has decreased by 1500 tons (70\%) since 2004, which corresponds to almost $30 \%$ reduction in the whole annual phosphorus load into the Gulf of Finland. In Poland, major investments have been carried out in the wastewater treatment sector, where sewage treatment is now available to much more people than in previous years. In addition, existing treatment facilities have been improved and only three upgraded major plants have meant that sewage from more than three million Polish citizens is now better cleansed. In Estonia, Latvia and Lithuania similar improvements have taken place leading to the deletion of for instance the Riga, Kaunas and Klaipeda wastewater treatments plants from the HELCOM List of Hot Spots.

Yet, the nitrogen inputs have not decreased as swiftly as those of phosphorus as a result of increased agricultural activities (Table 5).

$<$ Insert Table 5 Here $>$

In reality, the amount of nutrients entering the Baltic Sea is still very high - at least from the point of view of the goal of sustainability. However, it is true that the country pattern is very different, as the post-Communist countries have reduced their emissions considerably. But at the same time, the other countries have hardly decreased their emissions much (Table 6).

However, the crux of the matter is that the Baltic Sea cannot take even these reduced nutrient pollution amounts - year in and year out. Sustainability requires more effort, i.e. additional costs.

$<$ Insert Table 6 Here $>$

\subsubsection{Hypoxia}

Hypoxia is a well-described phenomenon in the offshore waters of the Baltic Sea with both the spatial extent and intensity of hypoxia known to have increased due to anthropogenic eutrophication. Helcom now reports on the widespread unprecedented occurrence of hypoxia across the coastal zone of the Baltic Sea. It has identified 115 sites that have experienced hypoxia during the period 1955-2009 increasing the global total to ca. 500 sites. Most sites experienced episodic hypoxia, which is a precursor to development of seasonal hypoxia. The Baltic Sea coastal zone displays, according to Helcom data, an alarming trend with hypoxia steadily increasing with time since the 1950s, effecting nutrient bio-geochemical processes, ecosystem services, and coastal habitat.

The Baltic Sea has received lots of heavy metals emissions over the years through the rivers or airborne. Although Helcom does not report any overall calculations of total emissions of hazardous substances, it states that the situation now has hardly improved much.

\subsubsection{Heavy Metals}

Hazardous substances include contaminants such as dioxins, PCBs, TBT, PFOS and heavy metals. Once released into the sea, hazardous substances can remain in the marine environment for very long periods and accumulate in the marine food web. Hazardous substances cause adverse effects in ecosystems. Some fish caught in the Baltic Sea contain concentrations of hazardous substances that exceed maximum allowable levels for foodstuffs as defined by the EU. Hazardous substances in the Baltic Sea include: substances that do not occur naturally in the environment, such as PCBs, DDTs, dioxins, TBT, nonylphenolethoxylates (NP/NPE), short-chained chlorinated paraffins (SCCP), brominated flame retardants (PBDEs) and certain nitromusks, which substances occurr at concentrations exceeding natural levels, including heavy metals like lead, copper, cadmium and mercury.

The Baltic Sea is one of the most intensely trafficked marine areas in the world. Both the numbers and the sizes of ships have grown in recent years, especially oil tankers, and this trend is expected to continue. The Baltic's narrow straits and shallow waters, many of which are covered by ice for prolonged periods in winter, make navigation very challenging, and increase the risk of shipping accidents. The main environmental effects of shipping and other activities at sea include air pollution, illegal deliberate and accidental discharges of oil, hazardous substances and other wastes, and the unintentional introduction of invasive alien organisms via ships' ballast water or hulls.

Increasing numbers of non-native species are being observed in seas all around the world, and the Baltic Sea is no exception. Shipping is the most important vector of unintentional species introductions into aquatic environments due to releases of ballast water and the fouling of hulls. Hazardous substances can accumulate in the marine food web up to levels which are toxic to marine organisms, particularly predators, and they may also represent a health risk for people. Once released into the Baltic Sea, hazardous substances can remain in the water for very long periods. Certain contaminants may be hazardous because of their effects on hormone and immune systems, as well as their toxicity, persistence and bio-accumulating properties. 
Helcom presents the following summary: "The gradual pollution of the Baltic marine environment by hazardous substances has caused a serious threat to the environment, and may even threaten the health of future generations. Although monitoring indicates that the loads of some hazardous substances have been reduced considerably over the past 20-30 years, problems still persist. There is still too little comprehensive knowledge about the impact of the most widely used chemicals and their cocktail-like combinations on human health and the environment. Relatively few organic pollutants are fully understood or even identified today. Another problem is that the degradation and transformation of these substances in the marine environment may change their structure and reactive properties. These unknown substances could pose a considerable threat to the environment." (http://www.helcom.fi/BSAP/ActionPlan/en_GB/SegmentSummary/)

\subsubsection{Overfishing}

Total fish catches have increased tenfold since the early 20th century as a result of more effective open sea fishing, decreased predation by seals and increased fish production due to eutrophication. Eutrophication may lead to reductions in the reproductive success of many fish species. Overexploitation of fish stocks in the Baltic is today common despite the objectives of the EU CFP to ensure exploitation of living aquatic resources that provides "sustainable economic, environmental and social condition". A lack of oxygen in established spawning areas combined with overfishing has drastically reduced cod catches in the Baltic Sea since the mid 1980s. The spawning stock biomass of herring has been decreasing steadily due to the unfavourable changes induced by falling salinity levels, in the zooplankton communities the herring feed on.

Helcom presents the following summary: "The populations of commercially important species such as cod and salmon are declining due to overexploitation and environmental degradation. Current levels of fishing for the most commercially important species are unsustainable. Despite repeated recommendations from the International Council for the Exploration of the Seas (ICES) for a complete closure of the eastern cod fishery until a long-term management plan has been adopted and has come into force, cod fisheries under the EU Common Fisheries Policy continues." (http://www.balticuniv.uu.se/index.php/download/doc_view/35-helcom-fisheries)

\subsection{Summing Up}

Admitting that the empirical evaluation above has concentrated upon only a few indicators on environmental pressure (Agrawal, 2003), it still is warranted to claim that the pressure upon the ecological system of the Baltic Sea has not improved since the fall of the Berlin Wall, when it was revealed that the former Communist states had engaged in massive pollution. It is true that the amount of inflows of phosphate and nitrogen has not increased after 1990, but it also holds that the total amount has not decreased. They remain at a high and unsustainable level. Lots of policy measures have of course been taken with all the EU funds backing up the Helcom regime, but rapid rates of development in all Baltic states increase the amount of pollution year by year. When other sources of environmental pressure are added, then one may actually argue that sustainability has been reduced.

\section{Explanation}

The evidence from the long series of Helcom evaluations does not warrant the conclusion that the Baltic Sea regime in collaboration with the environmental policies of the EU has succeeded in undoing a tragedy of the commons in this huge and important area. One may easily imagine the difficulties that the protection of other huge sea areas in the world faces, as they could hardly benefit from a more concerted and well-informed effort than that of the Baltic Sea regime together with EU financing.

One must be sceptical about the theory that self-governance among the parties concerned can solve the PD games, involved in the tragedy of the commons (Ostrom, 1990, 2000). The coastal states to the Baltic Sea have engaged in large scale coordination together with the EU and its formidable resources in order to halt the degradation of the Baltic Sea, which suffered so much from Communist negligence towards environmental values. However, sustainability has hardly increased. Despite numerous activities and measures, the total input of pollution from various sources to the Baltic Sea remains at a high level. Why, then, has not more been accomplished in protecting the Baltic Sea as a common pool of many states? The international regime is in place, but it is not as efficient as is necessary for sustainability. The theory of common pools governance has three weaknesses.

\subsection{Teleology}

In the governance of a common pool resource, one may find a teleological assumption about state behaviour in the sense that governments would naturally wish to implement most desirable solutions to the problem of managing common pool resources. This is not an innocuous one, because it is in its turn based on assumptions about the preferences schedules of the leaders in the state that may not be true. Why would the state always act functionally in 
relation to common pool resources? There could be opportunistic behaviour with state players, "opportunism" meaning guileful self-interest seeking.

Theoretically, the tragedy of the commons problem like, for instance, that of the Baltic Sea is modelled as a Prisoners' Dilemma game. Whereas the classical statements about the difficulties in arriving at first-best solutions in relation to common-pool resources were pessimistic (Hardin and Baden 1977), the new institutionalism has brought an optimistic tone into the debate (Ostrom 1992a). It is claimed that the collective action difficulties in protecting common-pool resources may be overcome by the establishment by means of voluntary exchange mechanisms of institutional principles that guard against the depletion or destruction of the common pool (Ostrom 1992b). However, such a claim is based upon teleological assumptions about the set of feasible and desirable state strategies which may not hold in reality.

The model of the Prisoners' Dilemma for the analysis of the tragedy of the commons starts from the assumption that states confronting collective action problems may develop meta-strategies in order to reach coordination landing on the cooperative strategy. As long as there is likelihood that the interaction between the participants will be reiterated, the reciprocal choice of a tit-for-tat strategy will result in the choice of the Pareto-optimal solution, i.e. cooperation for environment protection (Axelrod 1984). Slowly, the common-pool resources problem will become manageable by means of a voluntary exchange mechanism, leading to agreements that are self-enforceable among the participant actors (Ostrom et al. 1993), if tit-for-tat really works as participants grow in number.

States employ a special institution to make the collective action problem of common-pool resources manageable, viz. the identification and implementation of a so-called international regime. International regimes offer "social institutions governing the members of the international society" (Young 1989, 6). If such an international regime is extensive, comprises a number of rules, and is backed by organizational resources, then it could constrain its members towards first-best solutions (Krasner 1982). International negotiations leading to institutional regime choice would thus be instrumental in overcoming the collective action difficulties in protecting common-pool resources. The crux of the matter is that the real preferences and behaviour of some states may not fit with the presuppositions of the governance model in relation to the tragedy of the commons.

\subsection{Logic of Collective Action with Vengeance}

The management of common-pool resources involves collective action problems. Assuming individual rationality, will protecting the commons as a public good be forthcoming on the basis of voluntary exchange only? No single actor has the incentive to allocate these public goods because of the $\mathrm{N}-1$ and $1 / \mathrm{N}$ problems. As long as a group of size $\mathrm{N}$ members protects the commons by not using the commons, the N-1 actor would always benefit from exploiting the commons. If one actor allocates the public goods, i.e. does not exploit the commons, then $\mathrm{s} / \mathrm{he}$ could at best only hope for $1 / \mathrm{N}$ share of the benefits from her/his contribution.

The existence of $\mathrm{N}-1$ and $1 / \mathrm{N}$ collective action problems in relation to the allocation of a good implies that that there will be an undersupply of the good (Olsen 1965). However, if the preferences of the actors have a specific shape and there is reiterative interaction, then institutional solutions could be introduced. Policy-making towards sustainability of common pools involves two kinds of deliberations:

(1) Feasibility: Are there options that the state may realistically pursue that have a probable impact upon the amelioration of the tragedy of the commons? The information function reflects the technology available in society.

(2) Desirability: Are some of the feasible programmes worth undertaking? The evaluation of the expected value of alternative policies reflects not only the objective costs involved in each programme but also the subjective marginal willingness to pay.

Despite the underlying pessimistic tone in the tragedy of the commons literature, there could be hope in relation to the tragedy of the commons when it is modelled as a governance problem. State players could offer an institutional mechanism for the prevention of the tragedy of the commons. Whether the state will take such action to attempt to protect the common-pool resources around its borders depends, though, on both its capacity to act (feasibility) and its preferences when international regimes are to be set up (desirability).

\subsection{Government Preferences}

First, a state may not be able to cooperate in the management of the common pool resources, as it may simply lack the resources necessary to take action to protect the commons. If first-best solutions are not achievable, then the tragedy of the commons is unavoidable. Second, a state may not wish to cooperate in the management of common-pool resources. 
The management of common-pool resources may involve collective action problems at the same time as the players look upon the situation differently and defend asymmetric interests.

States that take part in the creation of an international regime may make very different deliberations about what the pros and cons of alternative schemes are. With regard to ecology and environmental issues, states may differ considerably on how they estimate risk, hazard and opportunity, not to say costs (Wildavsky 1987). The variety of orientations among states to the outcomes of the tragedy of the commons will reflect such countries' opinions, particularly among those people who have a decisive influence on policy-making in the field of ecology.

States differ considerably on preferences concerning both feasibility and desirability of sustainable policy-making. The boundaries of the set of feasible policies are drawn by, on the one hand, the access to advanced information, and on the other hand by the possession of economic resources to be employed at the implementation stage. The set of desirable policies may be either large or small depending upon the values at stake. Finally, the joint set of feasible and desirable policies may as a matter of fact be empty, because the desirable programmes are not feasible or the feasible policies are not considered worth their costs. Policy feasibility being determined by available technological knowledge and policy desirability expressing the variety of preferences among leaders, it is small wonder that there will be sharp differences both between states as well as over time in the capacity and willingness of governments to take part in international regimes.

Combining ecological activities from both state A (rich) and state B (poor), the pollution and depletion of the Baltic Sea could certainly be counteracted: the more activities or the more efficient the policy measures, the more the common pool resources would be protected. Yet, the costs of such activities may be expected to differ widely between the rich and the poor states, as very elementary policies are needed in the poor state, whereas the addition of new policies to an already existing set-up would come at considerable cost to the rich state. The arrival of the rich and poor states at a cooperative strategy is based not only upon the activities that the rich states undertake themselves to combat pollution and depletion, but also upon the contribution of the rich states to the initiation and implementation of activities by the poor states that would reduce pollution and depletion.

As the data about the Baltic Sea indicate, neither state A or state B may be capable or willing to put in place a truly sustainable regime that would significantly reduce pollution. As higher levels of affluence become possible in both the rich and the poor state, new forms of pollution arrive, constant overuse threatening the sustainability of common pool. Neither state A nor state B may be willing to take on the true costs for reversing the depletion of the common pool. Since 1990, anti-pollution measures have been implemented, but they simply do not suffice for sustainability. Old sources of pollution are faced out, but new forms of pollution arrive with expanding affluence and higher levels of economic activity. For instance, air borne pollution and pollution from shipping has increased considerably.

\section{Conclusion}

In view of the evidence from the CPR regime for the huge and important Baltic Sea, the stylised analysis of governing common pools (Keohane and Ostrom, 1994) appears too optimistic. The establishment of international ecology regimes to handle the tragedy of the common problem is beset with greater difficulties that are not fully recognized in this approach underlining voluntary coordination. Thus, when the club members of the CPR regime are sovereign states, there is bound to emerge opportunistic aspects of action, which make governments diverge from first-best solutions. In addition, a basic asymmetry between rich and poor countries invites the strategy of the latter exploiting the former by delaying participation or demanding complete external financing.

It is true that a few voluntary regimes have been successful in handling the efficient use of common pool resources, i.e. mainly examples of domestic irrigation schemes where actually the recourse to state intervention, for example complaint or litigation, is not entirely absent (Ostrom 1992a, 1992b; Young, 2011). However, these few cases must not derail our attention to massive failed environmental protection of open access resources, like the ongoing destruction of rain forests, the desertification of huge areas in Africa and India as well as the constant overfishing of seas and oceans.

When a regime like the HELCOM, set up by advanced countries and supported by the EU, has not been successful in radically improving the serious condition of the Baltic Sea, despite generous funding from the rich member states and the EU, then one understands the force of the PD dilemma in the tragedy of the commons as well as the difficulty in voluntary state coordination to promote environmental sustainability (Adger et al, 2003; Paavola, 2005).

When sovereign states collaborate in order to protect a common pool of great importance - like the Baltic Sea, then the outcome is entirely voluntary. The regime agency - HELCOM - is neither a police nor a court, but only an information 
ot monitoring gathering body. Yet, the chief finding is that the overall predicament of this common pool, the Baltic Sea, is not sustainable.

It its most recent report, HELCOM (2012) advises its member states to take strong measures to reduce pollution over the Baltic Sea in order to reach sustainability. Thus, the emissions of N and P loads must come down. CPR governance is not a sufficient condition for environmental sustainablity, not even when the players involved are so-called well-ordered societies with lots of funding to draw upon.

\section{References}

Adger, W. N., K. Brown, J. Fairbrass, A. Jordan, J. Paavola, S. Rosendo, \& G. Seyfang. (2003). Towards a thick analysis of environmental decisions. Environment and Planning A, 35, 1095-1110.

Adhikari, B. (2001). Literature Review on the Economics of Common Property Resources. University of York: Centre for Ecology, Law and Policy.

Agrawal, A. (2002). Common Resources and Institutional Sustainability. In E. Ostrom, T. Dietz, N. Dolšak, P.C. Stern, S. Stonich, and E.U. Weber (Eds.), The Drama of The Commons. Washington, D.C., National Academy Press.

Agrawal, A. (2003). Sustainable Governance of Common Pool Resources: Context, Methods, and Politics. Annual Review of Anthropology, 32, 243-62.

Axelrod, R. (1984). The Evolution of Cooperation. New York: Basic Books.

Baden, J. A., \& D. S. Noonan, (eds). (1998). Managing the Commons. Bloomington. Indiana University Press.

Clark, J., \& A. Wildavssky. (1991). The Moral Collapse of Communism. Richmond, CA: ICS Press.

Hardin, G. (1968). The Tragedy of the Commons. Science, 162, 1243-1248.

Hardin, G., \& Baden, J. (eds). (1977). Managing the Commons. San Francisco: W.W. Freeman.

Hardin, R. (1982). Collective Action. Washington, DC: RFF Press.

HELCOM. (1990). Baltic Sea Environment Proceedings, no. 358. Periodic Assessment of the State of the Marine Environment of the Baltic Sea, 1984-1988. Background Document. Helsinki.

HELCOM. (1993). The Baltic Sea Joint Comprehensive Environmental Action Programme. Baltic Sea Environment Proceedings No. 48. Helsinki.

HELCOM. (2004). The Fourth Baltic Sea Pollution Load Compilation (PLC-4), Baltic Sea Environment Proceedings No. 93. Helsinki.

HELCOM. (2007). HELCOM Baltic Sea Action Plan. Helsinki. [Online] Available: http://www.helcom.fi/BSAP/ActionPlan/

HELCOM. (2010). Hazardous substances in the Baltic Sea - An integrated thematic assessment of hazardous substances in the Baltic Sea. Balt. Sea Environ. Proc. No. 120B. Helsinki.

HELCOM. (2010). Waterborne loads of nitrogen and phosphorus to the Baltic Sea in 2008. [Online] Available: http://www.helcom.fi/BSAP_assessment/ifs/ifs2010/en_GB/nutrient_load/

Helcom. (2012). Fifth Baltic Sea Pollution Load Compilation. Baltic Sea Environment Proceedings No 128. Helsinki. [Online] Available: http://www.helcom.fi/stc/files/Publications/Proceedings/BSEP128.pd

Keohane, R. O., \& Ostrom, E., (eds). (1994). Local Commons and Global Interdependence. Special issue of Journal of Theoretical Politics, 6, 4.

Krasner, S. D. (1982). International Regimes. Ithaca, NY: Cornell University Press.

Ostrom, E. (1990). Governing the Commons: The Evolution of Institutions for Collective Action. Cambridge: Cambridge University Press.

Ostrom, E. (1992a). Crafting Institutions for Self-Governing Irrigation Systems. San Francisco: SanC Press.

Ostrom, E. (1992b). Institutions and Common Pool Resources. Special issue of the Journal of Theoretical Politics, 4, 3.

Ostrom, E. (2000). Collective Action and the Evolution of Social Norms. Journal of Economic Perspectives, 14(3), $137-158$ 
Ostrom, E., J. Burger, C. Field, R. Norgaaed, \& D. Policansky. (1999). Revisiting the Commons: Local Lessons, Global Challenges. Science, 284, 278-282.

Ostrom, E., Schroeder, L., \& Wynne, S. (1993). Institutional Incentives and Sustainable Development. Boulder, CO: Westview Press.

Ostrom, E., T. Diez, N. Dolsak, P. Stern, S. Stonich, \& U. W. Elke, (eds). (2002). The Drama of the Commons. Washington, DC: National Academy Press.

Paavola, J. (2005). Environmental Conflicts and Institutions as Conceptual Cornerstones of Environmental Governance Research. CSERGE Working Paper EDM 05-01. Centre for Social and Economic Research on the Global Environment, University of East Anglia, Norwich.

Sandberg, M. (2007). Green Post-Communism? London: Routledge.

Wildavsky, A. (1987). Choosing Preferences by Constructing Institutions: a Cultural Theory of Preference Formation. American Political Science Review, 81, 3-21.

Young, O. R. (1982). Resource Regime: Natural Resources and Social Institutions. Berkeley: University of California Press.

Young, O. R. (1989). International Cooperation: Building Regimes for Natural Resources and the Environment. Ithaca, NY: Cornell University Press.

Young, O. R. (2005). Why Is There No Unified Theory of Environmental Governance? In P. Dauvergne (Ed.), Handbook of Global Environmental Politics (pp. 170-184). Cheltenham, UK: Edward Elgar.

Young, O. R. (2008). Building Regimes for Socioecological Systems: Institutional Diagnostics. In O. R. Young, L. A. King, and H. Schroeder (Eds.), Institutions and Environmental Change: Principal Findings, Applications, and Research Frontiers (pp. 115-144). Cambridge: MIT Press.

Young, O. R. (2011). Land use, environmental change, and sustainable development: the role of institutional diagnostics. International Journal of the Commons, 5(1), 66-85.

Table 1. Total Phosphorus (P) Loads into the Baltic Sea in 1990 (tons/year)

\begin{tabular}{lrrrr}
\hline Subarea & Rivers & Urban Areas & Industries & Total \\
\hline Bay of Bothnia & 2134 & 49 & 162 & 2345 \\
Bothnian Sea & 1851 & 56 & 356 & 2265 \\
Archipelago Sea & 664 & 31 & 140 & 835 \\
Gulf of Finland & 7642 & 4078 & 70 & 11790 \\
Gulf of Riga & 2705 & 649 & 34 & 3389 \\
Baltic Proper & 14158 & 2902 & 747 & 17807 \\
Belt Sea and Western Bays & 1699 & 964 & 124 & 2787 \\
The Sound & 234 & 328 & 100 & 1882 \\
The Kattegat & 1281 & 10616 & 1851 & 44824 \\
\hline Total & 32358 & & & \\
\hline
\end{tabular}

Source: HELCOM (1993) The Baltic Sea Joint Comprehensive Environmental Action Programme. 
Table 2. Total Nitrogen (N) Loads into the Baltic Sea in 1990 (tons/year)

\begin{tabular}{lrrrr}
\hline Subarea & Rivers & Urban Areas & Industries & Total \\
\hline Bay of Bothnia & 35034 & 1630 & 1567 & 38231 \\
Bothnian Sea & 42985 & 1399 & 3097 & 47481 \\
Archipelago Sea & 7870 & 940 & 1101 & 9911 \\
Gulf of Finland & 109530 & 30045 & 868 & 140443 \\
Gulf of Riga & 11730 & 5061 & 281 & 17072 \\
Baltic Proper & 159176 & 24660 & 2463 & 186299 \\
Belt Sea and Western Bays & 38821 & 7072 & 311 & 47476 \\
The Sound & 7591 & 6815 & 852 & 14717 \\
The Kattegat & 41340 & 4374 & 12122 & 46565 \\
\hline Total & 454077 & 81994 & & 548195 \\
\hline
\end{tabular}

Source: HELCOM (1993).

Table 3. Organic Matters (BOD7) Load into the Baltic Sea in 1990 (tons/year)

\begin{tabular}{lrrrr}
\hline Subarea & Rivers & Urban Areas & Industries & Total \\
\hline Bay of Bothnia & 79793 & 2731 & 18457 & 100981 \\
Bothnian Sea & 88536 & 1055 & 58298 & 147889 \\
Archipelago Sea & 7780 & 742 & 202 & 8274 \\
Gulf of Finland & 201935 & 70027 & 14324 & 286286 \\
Gulf of Riga & 101807 & 38923 & 863 & 141593 \\
Baltic Proper & 529862 & 60003 & 19336 & 609201 \\
Belt Sea and Western Bays & 4528 & 20804 & 24142 & 49475 \\
The Sound & 489 & 8148 & 8022 & 16658 \\
The Kattegat & 8227 & 4843 & 10935 & 24005 \\
\hline Total & 1002957 & 207276 & 154578 & 1384811 \\
\hline
\end{tabular}

Source: HELCOM (1993).

Table 4. Country source of pollution in 1990 (tons/year)

\begin{tabular}{lrr}
\hline Country & Total Nitrogen & Total Phosphorus \\
\hline Denmark & 8655 & 1994 \\
Sweden & 25900 & 565 \\
Finland & 30200 & 900 \\
Russia & 108824 & 7934 \\
Estonia & 39800 & 2174 \\
Latvia & 6775 & 1028 \\
Lithuania & 25830 & 2850 \\
Poland & 246185 & 21495 \\
Germany & 28860 & 2337 \\
\hline
\end{tabular}

Source: HELCOM (1990). 
Table 5. Riverine, coastal and direct point and diffuse source inputs of $\mathrm{N}_{\text {total }}$ of 9 countries in 1994-2008 as totals, $t / \mathrm{a}$

\begin{tabular}{lllllllllll}
\hline COUNTRY & Denmark & Estonia & Finland & Germany & Latvia & Lithuania & Poland & Russia & Sweden & Total Baltic \\
\hline 1994 & 97540,6 & 24400,9 & 60364,5 & 43556,3 & 114120,7 & 64922,6 & 266068,5 & $\mathrm{n} / \mathrm{a}$ & 129991,8 & 800965,9 \\
1995 & 68428,3 & 32185,1 & 67605,9 & 27192,2 & 91708,4 & 36041,9 & 220514,8 & $\mathrm{n} / \mathrm{a}$ & 129240,8 & 672917,2 \\
1996 & 34407,7 & 16813,1 & 65842,0 & 12081,5 & 51413,3 & 41999,2 & 264381,5 & $\mathrm{n} / \mathrm{a}$ & 87084,5 & 574022,8 \\
1997 & 36274,0 & 25737,6 & 64239,4 & 12173,2 & 92238,4 & 55835,6 & 221599,1 & $\mathrm{n} / \mathrm{a}$ & 97351,1 & 605448,4 \\
1998 & 76393,9 & 38787,8 & 86406,8 & 30622,9 & 107471,2 & 79901,5 & 278452,7 & $\mathrm{n} / \mathrm{a}$ & 157905,0 & 855941,9 \\
1999 & 73557,5 & 30965,3 & 67227,6 & 24774,3 & 78535,0 & 66378,6 & 221943,9 & $\mathrm{n} / \mathrm{a}$ & 144265,7 & 707647,9 \\
2000 & 58973,3 & 26874,0 & 101368,0 & 18600,9 & 67492,8 & 49818,1 & 191737,3 & 72124,6 & 151069,5 & 738058,5 \\
2001 & 52958,3 & 36192,3 & 74573,4 & 17540,5 & 79609,6 & 37334,5 & 204341,4 & 72539,4 & 138329,1 & 713418,6 \\
2002 & 69427,9 & 30430,1 & 51021,8 & 32426,3 & 68023,5 & 43527,8 & 252334,0 & 87465,5 & 118961,5 & 753618,4 \\
2003 & 35174,8 & 22327,6 & 52934,6 & 9967,7 & 40726,0 & 23422,2 & 137028,6 & 95671,0 & 79354,1 & 496606,6 \\
2004 & 54794,4 & 39037,0 & 82288,9 & 16080,6 & 79842,9 & 39927,2 & 157608,0 & 94141,3 & 114439,4 & 678159,7 \\
2005 & 42619,8 & 32583,3 & 78435,3 & 17573,9 & 69937,0 & 43777,3 & 146303,0 & 14351,9 & 103774,3 & 549355,7 \\
2006 & 52747,7 & 20411,4 & 78946,2 & 16880,3 & 59519,6 & 27964,7 & 152611,9 & 107556,3 & 120985,6 & 637623,7 \\
2007 & 54393,1 & 29966,2 & 81310,6 & 24054,0 & 95253,9 & 49491,7 & 179228,7 & 78468,1 & 134114,9 & 726281,0 \\
2008 & 42611,7 & 46229,8 & 100050,1 & 4255,1 & 89963,0 & 32845,1 & 144344,3 & n/a & 120330,5 & 580629,7 \\
\hline
\end{tabular}

Source: http://www.helcom.fi/BSAP_assessment/ifs/ifs2010/en_GB/nutrient_load/

Table 6. Riverine, coastal and direct point and diffuse source inputs of $P_{\text {total }}$ of 9 countries in 1994-2008 as totals, $t / a$

\begin{tabular}{lllllllllllll}
\hline Country & Denmark & Estonia & Finland & Germany & Latvia & Lithuania & Poland & Russia & Sweden & Total Baltic \\
\hline 1994 & 3621,4 & 1425,9 & 3507,5 & 955,4 & 2205,2 & 3985,8 & 13344,9 & 4192,0 & 4296,9 & 37534,9 \\
1995 & 2588,1 & 1316,0 & 3586,9 & 685,9 & 2060,5 & 1372,7 & 14265,4 & 9263,0 & 4721,7 & 39860,3 \\
1996 & 1602,7 & 735,6 & 3194,8 & 447,2 & 1009,6 & 1496,1 & 13461,9 & 4187,7 & 2438,7 & 28574,3 \\
1997 & 1488,9 & 937,5 & 3040,4 & 417,9 & 1471,1 & 2418,0 & 16882,8 & 3810,6 & 4061,2 & 34528,5 \\
1998 & 2039,0 & 1240,7 & 4475,1 & 716,9 & 2918,7 & 3228,1 & 16833,9 & 4048,8 & 4773,5 & 40274,6 \\
1999 & 2214,0 & 1748,1 & 3437,6 & 567,9 & 2148,6 & 3611,8 & 14740,1 & 3866,0 & 4729,5 & 37063,8 \\
2000 & 1864,9 & 965,0 & 4835,4 & 486,4 & 2207,0 & 1950,4 & 12555,4 & 6196,1 & 4946,4 & 36007,1 \\
2001 & 1715,0 & 1346,0 & 3407,0 & 457,9 & 2266,6 & 2733,7 & 13589,5 & 4376,7 & 4311,2 & 34203,5 \\
2002 & 2098,0 & 1237,4 & 2239,3 & 751,7 & 1862,9 & 3073,1 & 12957,5 & 5956,8 & 3154,6 & 33331,2 \\
2003 & 1198,0 & 1023,4 & 2001,5 & 345,6 & 1797,2 & 1324,1 & 8458,4 & 4746,1 & 2249,5 & 23143,9 \\
2004 & 1578,3 & 1501,6 & 3434,9 & 418,4 & 3120,6 & 2565,3 & 9746,0 & 7429,5 & 3341,6 & 33136,2 \\
2005 & 1717,7 & 1763,0 & 3382,4 & 387,9 & 2712,0 & 1358,8 & 8910,7 & 7565,3 & 3552,4 & 31350,1 \\
2006 & 1524,5 & 785,7 & 3488,2 & 487,1 & 2796,1 & 1241,3 & 10234,7 & 4071,6 & 3741,2 & 28370,4 \\
2007 & 2129,3 & 900,4 & 3291,8 & 598,1 & 3011,2 & 1968,3 & 9919,1 & 2695,1 & 3511,7 & 28025,1 \\
2008 & 2191,0 & 1369,6 & 5212,6 & 134,9 & 2928,1 & 1677,7 & 8137,4 & n/a & 3648,2 & 25299,3 \\
\hline
\end{tabular}

Source: http://www.helcom.fi/BSAP_assessment/ifs/ifs2010/en_GB/nutrient_load/ 